\title{
Application of Polyglycerol Mono-Fatty Acid Esters to Improve Breadmaking
}

\author{
Yoshiro Miyamoto ${ }^{* *}$, Mitsuhiro Sakamoto ${ }^{1}$, Tomoko Maeda ${ }^{2}$ and Naofumi Morita ${ }^{3 *}$ \\ ${ }^{1}$ Ako Laboratory, Research and Development Laboratory, Sakamoto Yakuhin Kogyo Co., Ltd., \\ 1325-93 Kizu, Ako, Hyogo 678-0165, Japan \\ ${ }^{2}$ Department of Life and Health Sciences, Hyogo University of Teacher Education, \\ 942-1 Shimokume, Yashiro, Hyogo 673-1494, Japan \\ ${ }^{3}$ Laboratory of Food Chemistry, Division of Applied Biochemistry, Graduate School of Agriculture and Biological Sciences, \\ Osaka Prefecture University, 1-1 Gakuencho, Sakai, Osaka 599-8531, Japan
}

Received July 13, 2004; Accepted October 27, 2004

\begin{abstract}
The effects of polyglycerol mono-fatty acid esters (PGMFEs) on dough properties and baking were investigated using six PGMFEs with saturated fatty acid moieties (octanoic, decanoic, lauric, myristic, palmitic, and stearic acids). The addition of the PGMFEs $(0.5 \% \mathrm{w} / \mathrm{w}$ of flour $)$ to dough significantly increased its resistance, retention of the generated gas, and the volume of bread compared to loaves baked with the addition of monoglycerides and the control. These effects increased with a decrease in the chain length of the fatty acid moiety of the PGMFEs. Microscopic observation of the fermented dough with the PGMFEs showed that the gluten matrix became thick and that most of the starch granules were sufficiently covered with the gluten matrix as compared with the control. Also, addition of the PGMFEs with palmitic or stearic acid moieties retarded firmness in bread like that of bread baked with monoglycerides. These results indicated that the addition of PGMFEs as dough-conditioners promoted gluten formation and retarded the firming of bread by acting as a softener.
\end{abstract}

Keywords: dough, breadmaking, dough-conditioner, softener, gluten, polyglycerol mono-fatty acid esters (PGMFEs)

\section{Introduction}

Polyglycerol mono fatty acid esters (PGMFEs), synthesized with polyglycerol and fatty acids, are bio-grade emulsifiers that are safe and offer multiple functional properties such as acid resistance, salt resistance, thermostability, savoriness, and superior $\mathrm{O} / \mathrm{W}$ emulsion. The PGMFEs are widely applied in the food industry and are often used as the aerating agents for cake (Nash and Knight, 1967; Hemker, 1981), antimicrobial agents (Conley and Kabara, 1973; Razavi-Rohani and Griffiths, 1994), and $\mathrm{O} / \mathrm{W}$ emulsifiers for coffee-whitener and mayonnaise (Miyamoto and Matsushita, 1988) etc. The PGMFEs are also applied in baked products such as cookies (Kuragano et al., 2000).

In general, emulsifiers are essential to the baking process and have been applied to baking for a long period. The main functions of the emulsifiers are to act as a dough-conditioner and a softener of bread. The effectiveness of emulsifiers as dough-conditioners mainly depends on gluten, which improves the mechanical tolerance of wheat dough and loaf volume. Dough conditioners, such as sodium stearoyl 2-lactylate or diacetyl tartaric acid ester of monoglyceride combine with gluten and the polar lipids in wheat flour. Consequently, the gluten-matrix becomes thick, covers the starch granules and makes the dough expand, hence the increase in loaf volume (Chung and Tsen, 1975; Jacobsberg et al., 1976). On the other hand, the effect of emulsifiers on the softness and shelf life of bread are mainly correlated with starch. Emulsifier combines with amylose in starch molecules and prevents it from re-crystallizing. Consequently, the bread keeps its softness.

The PGMFEs are generally utilized in breadmaking as dough conditioners. The addition of PGMFEs containing a lauric acid moiety increases the loaf volume of the bread more than those having stearic and oleic acid moieties (Garti and Aserin, 1981). However, it has not yet been elucidated how PGMFEs influence the loaf volume of the bread. Furthermore, the effects of the PGMFEs as the softeners for breadmaking have not yet been completely clarified. Recently, we reported that the PGMFEs affected the affinity of gluten and starch in the dough and that this depended strongly on the fatty acid moieties of the PGMFEs (Miyamoto et al., 2002). These results suggest that the PGMFEs function as the dough conditioner and the softener.

Thus, in this study, the authors describe the dough properties and bread qualities resulting from the addition of PGMFEs to wheat flour. Particularly, we emphasized on the effect of chain length of fatty acids moieties in the PGMFEs on the properties of dough and bread. The usefulness of the PGMFEs (Fig. 1) used in breadmaking was studied in comparison to that of monoglyceride.

E-mail: morita@biochem.osakafu-u.ac.jp (N. Morita). 


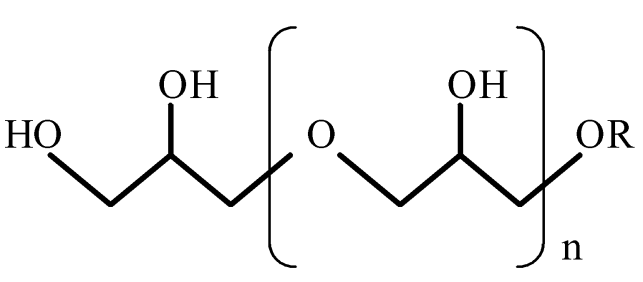

Fig. 1. Structure of monoglyceride or polyglycerol monofatty acid ester.

$\mathrm{R}=$ fatty acid moiety. $\mathrm{n}=0$ : monoglyceride, $\mathrm{n}=1$ or more : polyglycerol mono-fatty acid ester.

\section{Materials and Methods}

Materials Polyglycerol mono fatty acid esters (PGMFEs) were synthesized as follows. The polyglycerol used was POLYGLYCERIN \#750 (polyglycerol10: hydroxyl value $890 \mathrm{mg} \mathrm{KOH} / \mathrm{g}$; Sakamoto Yakuhin Kogyo Co., Ltd., Osaka). The polyglycerol and commercially available fatty acids; octanoic (10G-C8), decanoic (10 G-C10), lauric (10G-C12), myristic (10G-C14), palmitic (10 G-C16), and stearic (10G-C18) (98\% pure, NOF Co., Ltd., Tokyo) were made to concentrations of $1 \mathrm{M}$ each, and reacted with $0.1 \%$ of sodium hydroxide for $4 \mathrm{~h}$ at 220 $240^{\circ} \mathrm{C}$ under nitrogen gas flow at atmospheric pressure. The reactions were stopped when the acid value of the products became smaller than 1.0. The list of the PGMFEs used for the following experiments are shown in Table 1. The monoglyceride (glycerol monostearate: commercial grade, Riken Vitamin Co., Ltd., Tokyo) was used as a reference emulsifier. In all experiments, the PGMFEs and the monoglyceride ( $0.5 \%$ of flour weight) were suspended in distilled water at $55^{\circ} \mathrm{C}$ before use. The hard type wheat flour, Cameria, was obtained from Nisshin Flour Milling Co., Ltd. (Kobe).

Wheat dough properties Farinograph data (arrival, development, and stability times) of the dough made from wheat flour added with PGMFEs were obtained using a farinograph (Brabendar, Germany) with a $50 \mathrm{~g}$ stainless steel bowl according to the AACC method (54-21, 1994). Mixing was done at the standard speed of $63 \mathrm{rpm}$ at $30^{\circ} \mathrm{C}$. Extensograph data (resistance, extensibility, and area) of the dough was obtained using a Brabender extensograph based on the AACC method (54-10, 1994). The pasting curves of wheat flour containing the PGMFEs and changes in the apparent viscosity of the aqueous wheat flour suspension were determined as described previously (Maeda and Morita, 2002). The slurry of $60 \mathrm{~g}$ of wheat flour, $0.3 \mathrm{~g}$ of PGMFE, and $450 \mathrm{ml}$ of distilled water were heated from $30^{\circ} \mathrm{C}$ to $93^{\circ} \mathrm{C}$ at a rate of $1.5^{\circ} \mathrm{C} / \mathrm{min}$. After keeping at $93^{\circ} \mathrm{C}$ for $15 \mathrm{~min}$, the paste was cooled to $30^{\circ} \mathrm{C}$ at the same rate of $1.5^{\circ} \mathrm{C} / \mathrm{min}$. Finally, the paste was kept at $30 \mathrm{C}$ for $15 \mathrm{~min}$.

Gas production from the dough during fermentation Gas generation of the dough during fermentation was determined using a fermograph (Atto Co. Ltd., Osaka). One hundred and fifty grams of wheat flour, $2.25 \mathrm{~g}$ of sodium chloride, $9.0 \mathrm{~g}$ of sucrose, $1.8 \mathrm{~g}$ of dry baker's yeast (J.T. Foods Co., Ltd., Shizuoka), $0.5 \mathrm{~g}$ of PGMFE and the optimum amount of water were mixed for $10 \mathrm{~min}$ using
Table 1. List of polyglycerol mono-fatty acid esters.

\begin{tabular}{lc}
\hline & Abbreviation \\
\hline \hline Polyglycerol-10 monooctanate & $10 \mathrm{G}-\mathrm{C} 8$ \\
Polyglycerol-10 monodecanate & $10 \mathrm{G}-\mathrm{C} 10$ \\
Polyglycerol-10 monolaurate & $10 \mathrm{G}-\mathrm{C} 12$ \\
Polyglycerol-10 monomyristate & $10 \mathrm{G}-\mathrm{C} 14$ \\
Polyglycerol-10 monopalmitate & $10 \mathrm{G}-\mathrm{C} 16$ \\
Polyglycerol-10 monostearate & $10 \mathrm{G}-\mathrm{C} 18$ \\
\hline
\end{tabular}

the Ladies Mixer KN-200 (Taisho Denki Co., Ltd., Osaka). The optimum amount of water for each dough was determined from the water absorption ratio by the farinograph mixing at 500 Brabender Unit (B.U.). After mixing, the dough was divided into 6 pieces ( $35 \mathrm{~g} /$ piece) and placed into glass bottles (designed by Atto Co. Ltd.). Then the bottles were set to stand in a water bath at $30^{\circ} \mathrm{C}$ and the dough were fermented for $180 \mathrm{~min}$. The volumes of total and liberated gas were recorded by a computer program (Ferment digital recorder system version 3.0, Atto Co. Ltd.). However, the percentage of liberated gas from fermented dough was calculated by:

Leaked gas $=(\mathrm{mL}$ of total gas $-\mathrm{mL}$ of leaked-out gas $)$

$/(\mathrm{mL}$ of total gas $) \times 100$

Scanning electron microscopic observation The dough sample was prepared by the same procedure described for gas generation. A $10 \mathrm{~g}$ dough sample was then subjected to fermentation for $30 \mathrm{~min}$ in a cabinet at a constant temperature of $30^{\circ} \mathrm{C}$ and relative humidity of $85 \%$. The fermented dough sample was observed using a scanning electron microscope (SEM) (Hitachi Model S-800, Tokyo, Japan), as reported previously (Morita et al., 1996).

Bread baking The breadmaking formula and procedures were carried out using a slight modification of AACC methods (optimized straight-dough method 10-10 B, 1995; sponge-dough method 10-11, 1995). For the optimized straight-dough method, $300 \mathrm{~g}$ of wheat flour, 4.5 $\mathrm{g}$ of sodium chloride, $18 \mathrm{~g}$ of sucrose, $3.6 \mathrm{~g}$ of dry baker's yeast, $1.5 \mathrm{~g}$ of PGMFE and the appropriate amount of water were mixed for 15 min using a Ladies Mixer (KN200). The mixed dough was subjected to an initial fermentation for $90 \mathrm{~min}$ in a cabinet at $30^{\circ} \mathrm{C}$ and a relative humidity of $85 \%$. During fermentation, one punching was performed after $60 \mathrm{~min}$, before the dough was divided into 3 pieces ( $130 \mathrm{~g} /$ piece), rounded and molded using a mechanical molder SM-230 (Baker's Production Co., Ltd., Osaka), and placed in a baking pan. The dough was subjected to a final proof of $33 \mathrm{~min}$ in a cabinet maintained $38^{\circ} \mathrm{C}$ with a relative humidity of $90 \%$ before baking at $200^{\circ} \mathrm{C}$ for $20 \mathrm{~min}$.

The formula and procedure for the sponge-dough method were as follows: $180 \mathrm{~g}$ of wheat flour, $3.6 \mathrm{~g}$ of dry baker's yeast, $1.5 \mathrm{~g}$ of PGMFE, and the appropriate amount of water were mixed for $4 \mathrm{~min}$. The mixed 
Table 2. Summary of farinograph data of wheat dough samples containing PGMFEs.

\begin{tabular}{|c|c|c|c|c|}
\hline & Arrival time (min) & Development time (min) & Stability time (min) & Water absorption (\%) \\
\hline Control & $1.2^{\mathrm{ab}}$ & $20.0^{\mathrm{b}}$ & $28.3^{\mathrm{b}}$ & 67.6 \\
\hline monoGly & $0.9^{\mathrm{a}}$ & $18.7^{\mathrm{ab}}$ & $27.6^{\mathrm{b}}$ & 66.0 \\
\hline $10 \mathrm{G}-\mathrm{C} 8$ & $1.5^{\mathrm{ab}}$ & $16.3^{\mathrm{a}}$ & $22.9^{\mathrm{a}}$ & 67.2 \\
\hline $10 \mathrm{G}-\mathrm{C} 10$ & $1.9^{\mathrm{ab}}$ & $16.6^{\mathrm{a}}$ & $23.4^{\mathrm{a}}$ & 67.4 \\
\hline $10 \mathrm{G}-\mathrm{C} 12$ & $2.2^{\mathrm{b}}$ & $17.6^{\mathrm{ab}}$ & $23.7^{\mathrm{a}}$ & 67.6 \\
\hline $10 \mathrm{G}-\mathrm{C} 14$ & $1.6^{\mathrm{ab}}$ & $18.6^{\mathrm{ab}}$ & $25.7^{\mathrm{ab}}$ & 67.8 \\
\hline $10 \mathrm{G}-\mathrm{C} 16$ & $1.8^{\mathrm{ab}}$ & $17.2^{\mathrm{ab}}$ & $25.3^{\mathrm{ab}}$ & 68.2 \\
\hline $10 \mathrm{G}-\mathrm{C} 18$ & $1.0^{\mathrm{ab}}$ & $17.2^{\mathrm{ab}}$ & $26.1^{\mathrm{ab}}$ & 68.4 \\
\hline
\end{tabular}

Control, wheat alone; monoGly, monoglyceride. Other abbreviations are the same as in Table 1.

The same letter in the same column is not significantly different $(P<0.05)$. Values are average of two data.

sponge was allowed to ferment for $4 \mathrm{~h}$ under the same conditions described above. After the first fermentation, $120 \mathrm{~g}$ of flour, $6.0 \mathrm{~g}$ of sodium chloride, $15.0 \mathrm{~g}$ of sucrose and the appropriate amount of water were mixed for $15 \mathrm{~min}$. During mixing, the fermented sponge was added onethird each at 15, 25, and $35 \mathrm{~s}$. The mixed dough was then incubated for $30 \mathrm{~min}$ in a cabinet maintained at $30^{\circ} \mathrm{C}$ and a relative humidity of $85 \%$. Subsequently, the dough was divided into 3 pieces ( $130 \mathrm{~g} /$ piece), rounded and molded using the same mechanical mold, and placed in a baking pan. The dough was then subjected to a final proof for 50 min in a cabinet at $35.5^{\circ} \mathrm{C}$ and a relative humidity of $92 \%$, before baking at $218^{\circ} \mathrm{C}$ for $25 \mathrm{~min}$. After baking, the bread was removed and immediately weighed, and the loaf volume was measured by the rapeseed displacement method.

Measurement of firmness of bread during storage Staleness of bread was determined using a rheometer and data were processed as described previously (Morita et al., 2002). A sample of bread $\left(4 \times 4 \times 3 \mathrm{~cm}^{3}\right)$ was used with the plunger (2-cm diameter) was controlled at the compression depth of $7 \mathrm{~mm}$.

Statistical analyses Data were analyzed independently and at least in duplicate. Analysis of variance (ANOVA) was performed using Duncan's multiple-range test to compare the means of each treatment; differences were considered significant at $P<0.05$.

\section{Results and Discussion}

Dough properties The farinograph data of dough containing the PGMFEs during mixing are shown in Table 2. The arrival time did not differ markedly, but development and stability times were shorter than those of the control. The stability time of dough increased as the chain length of the fatty acid moieties of the PGMFEs increased. The water absorption ratios of the PGMFEs $(67.2-68.4 \%)$ and monoglyceride $(66.0 \%)$ were not observed to differ from that of the control $(67.6 \%)$. The water absorption of the dough increased as the chain length of
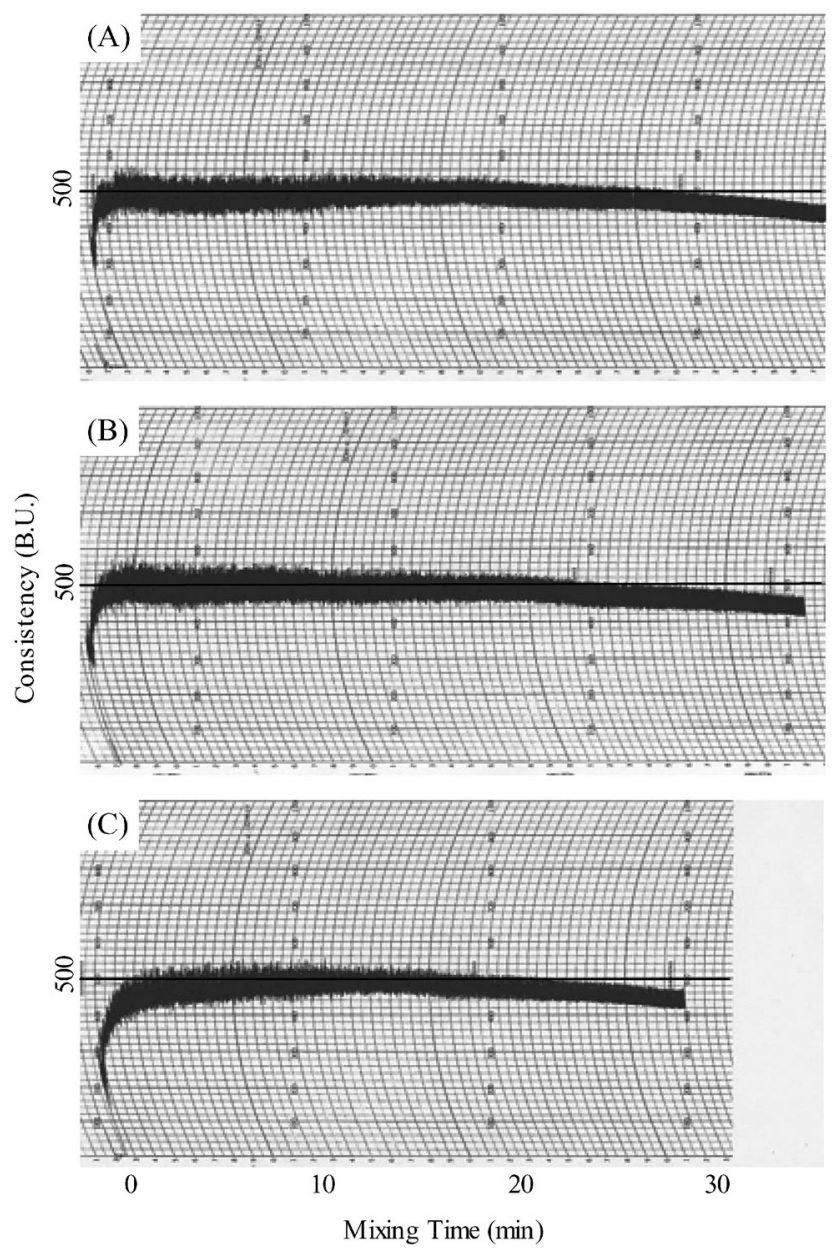

Fig. 2. Typical farinograms of dough sample containing PGMFE.

(A), Control ; (B), monoglyceride ; (C), 10G-C8.

the fatty acid moieties of the PGMFEs increased. Typical farinograms of dough containing 10G-C8 and monoglyceride are shown in Fig. 2.

Table 3 shows the summary of some extensibility data 
Table 3. Summary of extensograph data of wheat dough samples containing PGMFEs.

\begin{tabular}{cccc}
\hline & Resistance (BU) & Extensibility $(\mathrm{mm})$ & Area $\left(\mathrm{cm}^{2}\right)$ \\
\hline \hline Control & $560^{\mathrm{a}}$ & $188^{\mathrm{a}}$ & $142^{\mathrm{a}}$ \\
monoGly & $575^{\mathrm{a}}$ & $199^{\mathrm{a}}$ & $154^{\mathrm{ab}}$ \\
$10 \mathrm{G}-\mathrm{C} 8$ & $667^{\mathrm{d}}$ & $196^{\mathrm{a}}$ & $173^{\mathrm{c}}$ \\
$10 \mathrm{G}-\mathrm{C} 10$ & $643^{\mathrm{cd}}$ & $192^{\mathrm{a}}$ & $168^{\mathrm{bc}}$ \\
$10 \mathrm{G}-\mathrm{C} 12$ & $620^{\mathrm{bcd}}$ & $193^{\mathrm{a}}$ & $156^{\mathrm{abc}}$ \\
$10 \mathrm{G}-\mathrm{C} 14$ & $620^{\mathrm{bcd}}$ & $193^{\mathrm{a}}$ & $158^{\mathrm{abc}}$ \\
$10 \mathrm{G}-\mathrm{C} 16$ & $622^{\mathrm{bcd}}$ & $199^{\mathrm{a}}$ & $158^{\mathrm{abc}}$ \\
$10 \mathrm{G}-\mathrm{C} 18$ & $578^{\mathrm{ab}}$ & $198^{\mathrm{a}}$ & $157^{\mathrm{abc}}$ \\
\hline \hline
\end{tabular}

Abbreviations are the same as in Table 2 .

The same letter in the same column is not significantly different $(P<0.05)$. $\mathrm{n}=3$.
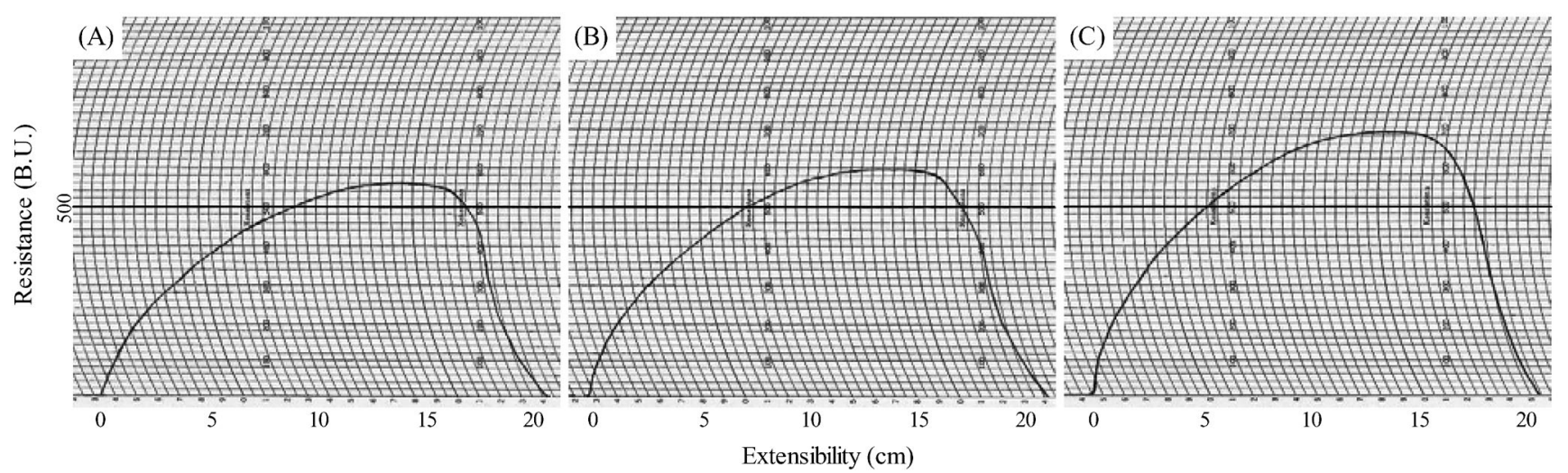

Fig. 3. Typical extensograms of wheat dough sample containing PGMFE.

(A), Control ; (B), monoglyceride ; (C), 10G-C8.

obtained from the extensograph test after $135 \mathrm{~min}$. The control dough had a resistance of 560 B.U., an extensibility of $188 \mathrm{~mm}$, and an area of $142 \mathrm{~cm}^{2}$. The resistance and area values for dough containing PGMFEs were significantly greater than those of the control. Especially, 10 G-C8 showed the highest resistance and area values among all the additives $\left(667\right.$ B.U. and $173 \mathrm{~cm}^{2}$, respective1y). The resistance and area values of the dough increased markedly with an increase in the chain length of the fatty acid moieties of the PGMFEs. However, the addition of the monoglyceride did not affect the extensograph test. These results indicated that the addition of the PGMFEs strengthens the gluten matrix with the chain length of the fatty acid moiety being primarily responsible. Typical extensograms of dough containing 10G-C8 and monoglyceride are shown in Fig. 3.

The changes in the apparent viscosity of the aqueous wheat flours containing PGMFEs measured by a Viscograph are shown in Table 4. The gelatinization temperature of starch in the dough containing the PGMFEs (59.8$61.0^{\circ} \mathrm{C}$ ) did not differ markedly from that of the control $\left(60.0^{\circ} \mathrm{C}\right)$. However, the maximum viscosity temperature, and the maximum and final viscosities were influenced by the addition of PGMFEs. Addition of 10G-C8, 10G-C10, and $10 \mathrm{G}-\mathrm{C} 12\left(90.3,90.6\right.$, and $91.0^{\circ} \mathrm{C}$, respectively) resulted in lower temperature than the control $\left(92.3^{\circ} \mathrm{C}\right)$, and the temperature decreased as the chain length of the fatty acid moieties of the PGMFEs decreased. In contrast, the addition of 10G-C12, 10G-C14, 10G-C16, and 10G-C18 resulted in increasing maximum viscosity above that of the control, and the viscosity increased as the chain length of the fatty acid moieties of the PGMFEs increased. At the final viscosity, there was a lowering effect of the viscosity in all the PGMFEs. Therefore, the addition of PGMFEs lowered the maximum viscosity temperature and final viscosity, whereas the maximum viscosity increased.

Effects of PGMFEs on gas production The total amount of $\mathrm{CO}_{2}$ gas generation and the ratio of the liberated gas from the dough containing the PGMFEs after $180 \mathrm{~min}$ of fermentation using a fermograph are shown in Table 5 . The total volumes of $\mathrm{CO}_{2}$ gas generated from the dough were almost fixed (174.4-177.2 ml) without relating to the addition of the PGMFEs. However, the ratio of liberated gas was lowered remarkably by 
Table 4. Summary of viscograph data of wheat dough containing PGMFEs.

\begin{tabular}{ccccc}
\hline & GT & MVT & MV & FV \\
\hline \hline Control & $60.0^{\mathrm{ab}}$ & $92.3^{\mathrm{b}}$ & $415^{\mathrm{ab}}$ & $1070^{\mathrm{d}}$ \\
monoGly & $61.0^{\mathrm{c}}$ & $92.1^{\mathrm{b}}$ & $395^{\mathrm{a}}$ & $810^{\mathrm{a}}$ \\
$10 \mathrm{G}-\mathrm{C} 8$ & $60.5^{\mathrm{abc}}$ & $90.3^{\mathrm{a}}$ & $405^{\mathrm{a}}$ & $905^{\mathrm{b}}$ \\
$10 \mathrm{G}-\mathrm{C} 10$ & $59.8^{\mathrm{a}}$ & $90.6^{\mathrm{a}}$ & $435^{\mathrm{b}}$ & $890^{\mathrm{b}}$ \\
$10 \mathrm{G}-\mathrm{C} 12$ & $60.7^{\mathrm{bc}}$ & $91.0^{\mathrm{a}}$ & $465^{\mathrm{c}}$ & $925^{\mathrm{b}}$ \\
$10 \mathrm{G}-\mathrm{C} 14$ & $60.5^{\mathrm{abc}}$ & $91.7^{\mathrm{b}}$ & $470^{\mathrm{c}}$ & $995^{\mathrm{c}}$ \\
$10 \mathrm{G}-\mathrm{C} 16$ & $60.4^{\mathrm{abc}}$ & $91.9^{\mathrm{b}}$ & $475^{\mathrm{c}}$ & $1020^{\mathrm{c}}$ \\
$10 \mathrm{G}-\mathrm{C} 18$ & $61.0^{\mathrm{c}}$ & $92.0^{\mathrm{b}}$ & $475^{\mathrm{c}}$ & $990^{\mathrm{c}}$ \\
\hline \hline
\end{tabular}

Abbreviations are the same as in Table 2.

GT, gelatinization $\left({ }^{\circ} \mathrm{C}\right)$; MVT, maximum viscosity $\left({ }^{\circ} \mathrm{C}\right)$; MV, maximum viscosity (BU); FV, final viscosity (BU).

The same letter in the same column is not significantly different $(P<0.05)$. Values are average of two data.

Table 5. Total gas generation and ratio of leaked gas from dough containing PGMFEs.

\begin{tabular}{ccc}
\hline & Total gas generation $(\mathrm{mL})$ & Ratio of leaked gas (\%) \\
\hline \hline Control & $174.6^{\mathrm{a}}$ & $21.2^{\mathrm{c}}$ \\
monoGly & $174.6^{\mathrm{a}}$ & $20.1^{\mathrm{c}}$ \\
$10 \mathrm{G}-\mathrm{C} 8$ & $176.7^{\mathrm{a}}$ & $12.4^{\mathrm{a}}$ \\
$10 \mathrm{G}-\mathrm{C} 10$ & $176.9^{\mathrm{a}}$ & $13.8^{\mathrm{a}}$ \\
$10 \mathrm{G}-\mathrm{C} 12$ & $175.3^{\mathrm{a}}$ & $15.6^{\mathrm{b}}$ \\
$10 \mathrm{G}-\mathrm{C} 14$ & $174.7^{\mathrm{a}}$ & $15.7^{\mathrm{b}}$ \\
$10 \mathrm{G}-\mathrm{C} 16$ & $174.4^{\mathrm{a}}$ & $16.7^{\mathrm{b}}$ \\
$10 \mathrm{G}-\mathrm{C} 18$ & $177.2^{\mathrm{a}}$ & $16.9^{\mathrm{b}}$ \\
\hline \hline
\end{tabular}

Abbreviations are the same as in Table 2.

The same letter in the same column is not significantly different $(P<0.05) . \mathrm{n}=3$.

the addition of the PGMFEs (12.4-16.9\%). This lowering effect decreased as the chain length of the fatty acid moiety of the PGMFEs decreased. Especially, the addition of $10 \mathrm{G}-\mathrm{C} 8$ generated the lowest total $\mathrm{CO}_{2}$ gas, which is lower than the control by about $9 \%$. Furthermore, the addition of monoglyceride $(20.1 \%)$ was almost similar to the control $(21.2 \%)$. These results indicated that the PGMFEs have the ability to promote the retention of gas without inhibiting the enzyme activity of the yeast.

SEM observations of fermented dough The SEM results for dough containing 10G-C8 and 10G-C18 after 30 min of fermentation are shown in Fig. 4. No distinct boundaries were observed between starch granules and gluten in the control (A). Addition of 10G-C18 (C) caused the starch granules to be covered with gluten, in addition to the filamentous or fibrous portions of dough. Moreover, addition of $10 \mathrm{G}-\mathrm{C} 8$ (B) tended to form a thick gluten matrix that covered most of starch granules contrary to the addition of 10G-C18. Therefore, the addition of the PGMFEs resulted in a thick gluten matrix and the starch granules were covered with gluten. This tendency appeared more strongly as the chain length of the fatty acid moiety of the PGMFEs decreased. These results suggest that the addition of the PGMFEs prevents the liberation of $\mathrm{CO}_{2}$ gas from the dough during fermentation by strongly combining to gluten and starch granules.

Baking results The results for the specific volume of bread containing the PGMFEs baked using the optimized straight-dough and sponge-dough methods are shown in Table 6. The addition of the PGMFEs remarkably increased the specific volume of bread made using both methods (4.67-5.02 $\mathrm{cm}^{3} / \mathrm{g}$; straight dough method, 5.28$6.31 \mathrm{~cm}^{3} / \mathrm{g}$; sponge dough method) as compared with the control (3.97 and $5.12 \mathrm{~cm}^{3} / \mathrm{g}$, respectively). Moreover, the 

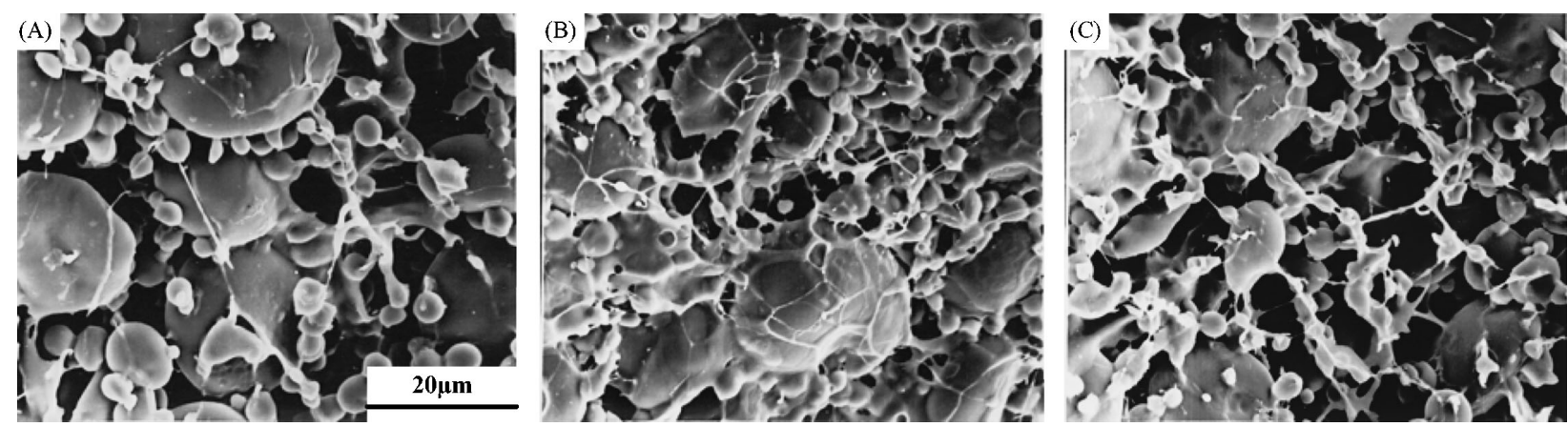

Fig. 4. Scanning electron micrographs of dough samples fermented for 30 min containing $0.5 \%$ PGMFEs. (A), control ; (B), 10G-C8 ; (C), 10G-C18.

Table 6. Effects of PGMFEs on the specific volume of bread made by straight or sponge-dough method.

\begin{tabular}{ccc}
\hline & Straight & Sponge \\
\hline \hline Control & $3.97^{\mathrm{a}}$ & $5.12^{\mathrm{a}}$ \\
monoGly & $4.41^{\mathrm{b}}$ & $5.37^{\mathrm{b}}$ \\
$10 \mathrm{G}-\mathrm{C} 8$ & $5.02^{\mathrm{e}}$ & $6.31^{\mathrm{e}}$ \\
$10 \mathrm{G}-\mathrm{C} 10$ & $4.91^{\mathrm{de}}$ & $5.90^{\mathrm{d}}$ \\
$10 \mathrm{G}-\mathrm{C} 12$ & $4.85^{\mathrm{cde}}$ & $5.68^{\mathrm{c}}$ \\
$10 \mathrm{G}-\mathrm{C} 14$ & $4.81^{\mathrm{cd}}$ & $5.61^{\mathrm{c}}$ \\
$10 \mathrm{G}-\mathrm{C} 16$ & $4.81^{\mathrm{cd}}$ & $5.55^{\mathrm{c}}$ \\
$10 \mathrm{G}-\mathrm{C} 18$ & $4.67^{\mathrm{c}}$ & $5.28^{\mathrm{ab}}$ \\
\hline \hline
\end{tabular}

Abbreviations are the same as in Table 2. Each value shows the specific volume $\left(\mathrm{cm}^{3} / \mathrm{g}\right)$ of bread.

The same letter in the same column is not significantly different $(P<0.05)$. $n=3$.

addition of the PGMFEs increased the specific volume of bread relative to the addition of monoglyceride except for 10G-C18 in the sponge-dough method. The specific volume of bread to which PGMFE of 10G-C8 had been added was $126 \%$ of the control using the optimized straight-dough method, whereas it was $123 \%$ using the sponge-dough method. Consequently, the addition of PGMFEs increased the specific volume of bread, in a way that was inversely proportional to the chain length of the fatty acid moieties in the PGMFEs.

Bread staleness The effects of the PGMFEs on the firmness of bread during storage at $25^{\circ} \mathrm{C}$ are shown in Fig. 5. The addition of PGMFEs softened the bread compared to the control. The bread with 10G-C18 PGMFEs was the softest, and its firmness was equivalent to that of the bread containing monoglyceride. This result indicated that PGMFEs prevent retrogradation of the bread as well as the monoglyceride.

The addition of the PGMFEs to wheat flour improved the loaf volume and retarded retrogradation of bread. The loaf volume of bread made from wheat flour with added PGMFEs was larger than that made using monoglycerides, but retardation of firmness was relatively similar. The effect of the fatty acid moiety in the PGMFEs on loaf volume of bread was similar to that observed for bread made with monoglyceride (Riisom et al., 1984). In a previous study (Miyamoto et al., 2002), the free lipid of the dough increased during mixing and was associated with the shorter chain lengths of the fatty acid in the PGMFEs. In general, the PGMFEs are more likely to form an $\alpha$ crystalline gel in aqueous solution than a monoglyceride (Lauridsen, 1976; Hemker, 1981). The tendency to form gels increases as the chain lengths of the fatty acid moiety of the PGMFEs decrease. It is thus quite possible for these short chain fatty acid moiety PGMFEs to become uniformly distributed in the dough during the mixing process, and because the amount of binding in gluten increases instead of to the lipid. Namely, the formation of the gluten matrix is promoted with the PGMFEs having short fatty acid chain, and the amounts of gas retention increases in the dough. Conversely, it is thought that the amount of PGMFEs having long fatty acid chain bonding to gluten is relatively low at the dough stage as well as the addition of the monoglyceride (Inoue et al., 1995). Therefore, these PGMFEs combine with the starch during baking and maintain the softness of the bread. Accordingly, we conclude that the PGMFEs are considerably good dough-conditioners and bread softeners.

\section{Conclusion}

The effects of PGMFEs on dough properties and the 


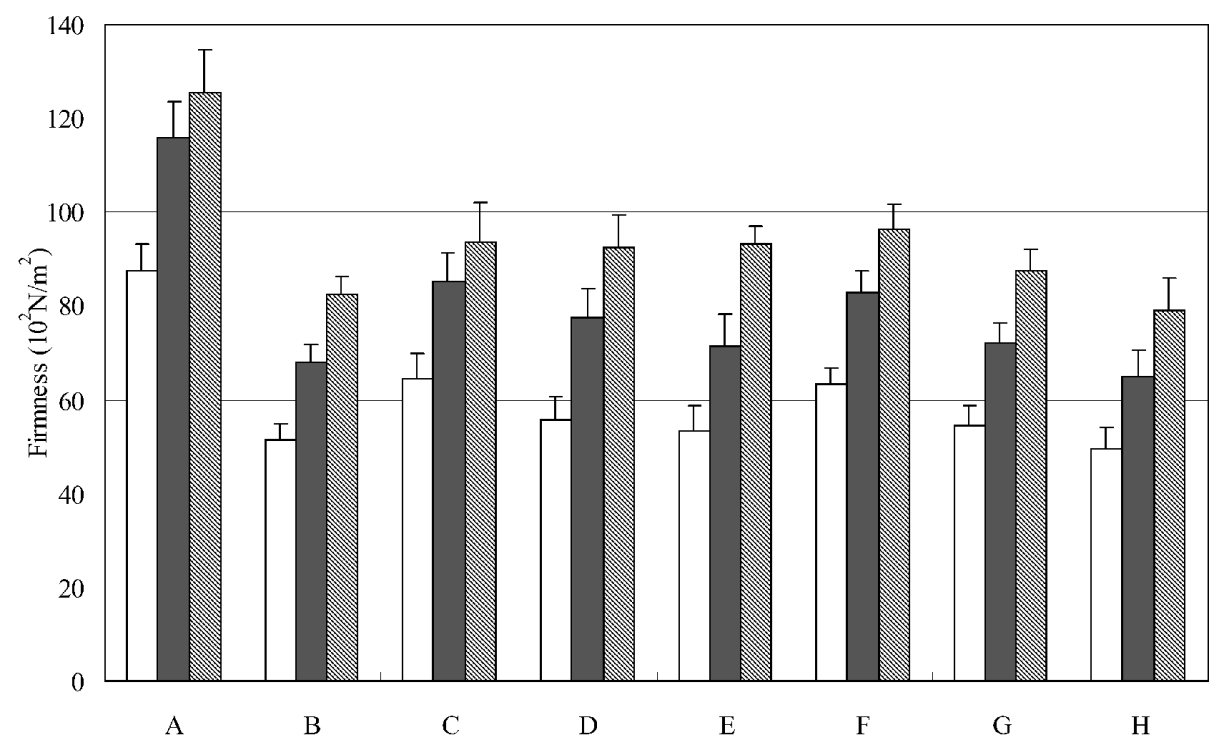

Fig. 5. Effects of PGMFEs on firmness of bread during storage for 3 days. $\square: 1$ day, $\square: 2$ days, 3 days.

A, control ; B, monoglyceride ; C, 10G-C8 ; D, 10G-C10 ; E, 10G-C12 ; F, 10G-C14 ;

G, 10G-C16 ; H, 10G-C18.

baking quality were investigated by using six PGMFEs with a saturated fatty acid moiety. We confirmed that the addition of PGMFEs significantly increased the gas retaining ability of fermented the dough and the loaf volume of the bread as compared with the monoglyceride. Regarding the microscopic structure of the dough to which PGMFEs had been added during fermentation, the gluten matrix became thick and covered the starch granules. Also, they were more enhanced with PGMFEs that have short saturated fatty acid chain.

\section{References}

American Association of Cereal Chemists. (1994). Approved Methods of the AACC (9th ed.). Method 54-21, approved April 1961, revised October 1994; Method 54-10, approved April 1961, revised October 1994. The association: St. Paul, MN.

American Association of Cereal Chemists. (1995). Approved Methods of the AACC (9th ed.). Method 10-10B, approved November 1995; Method 10-11, approved November 1995. The association: St. Paul, MN.

Chung, O.K. and Tsen, C.C. (1975). Changes in lipid binding and protein extractability during dough mixing in presence of surfactants. Cereal Chemistry, 52, 549-560.

Conley, A.A. and Kabara, J.J. (1973). Antimicrobial action of esters of polyhydric alcohols. Antimicrobial Agents and Chemotherapy, 4, 501-506.

De Stefanis, V.A., Ponte Jr., J.G., Chung, F.H. and Ruzza, N.A. (1977). Binding of crumb softeners and dough strengtheners during breadmaking. Cereal Chemistry, 54, 13-24.

Garti, N. and Aserin, A. (1981). Evaluation of polyglycerol fatty acid esters in the baking of bread. Bakers Digest, 55, 19-21.

Hemker, W. (1981). Associative structure of polyglycerol esters in food emulsions. Journal of the American Oil Chemists Society, $58,114-119$.

Inoue, S., Tugita, K., Koike, S., Maruzeni, S. and Kamoi, I. (1995). Effects of fatty acid species of monoglyceride on breadmaking properties. Nippon Shokuhin Kagaku Kougaku Kaishi, 42, 634-
642 (in Japanese).

Jacobsberg, F.R., Worman, S.L. and Daniels, N.W. (1976). Lipid binding in wheat-flour dough: the effect of DATEM emulsifier. Journal of the Science of Food and Agriculture, 27, 1064-1070.

Kuragano, T., Ueda T., Kubo M. and Katsuta K. (2000). Effect of polyglycerol fatty acid ester on the spread factor of cookie products. Nippon Kaseigaku Kaishi, 51, 41-48 (in Japanese).

Krog, N. (1971). Amylose complexing effect of food grade emulsifier. Starch, 23, 206-210.

Lauridsen, J.B. (1976). Food emulsifiers: Surface activity, edibility, manufacture, composition, and application. Journal of the American Oil Chemists Society, 53, 400-407.

Maeda, T. and Morita, N., (2002). Flour quality and pentosan prepared by polishing wheat grain on breadmaking. Food Research International, 36, 603-610.

Miyamoto, A. and Matsushita, K. (1988). Properties of polyglycerol esters and their uses in the food industry. New Food Industry, 30, 12-18 (in Japanese).

Miyamoto, Y., Sakamoto, M., Maeda, T. and Morita, N. (2002). Effects of polyglycerol mono-fatty acid esters on gluten and starch in wheat flour dough. Nippon Shokuhin Kagaku Kogaku Kaishi, 49, 534-539 (in Japanese).

Morita, N., Nakata, K., Hamauzu, Z. and Toyosawa, I. (1996). Effect of $\alpha$-glucosyl rutin as improvers for wheat dough and breadmaking. Cereal Chemistry, 73, 99-104.

Morita, N., Maeda, T., Miyazaki, M., Yamamori, M., Miura, H. and Ohtsuka I. (2002). Dough and baking properties of highamylose and waxy wheat flours. Cereal Chemistry, 79, 491-495.

Nash, N.H. and Knight, G.S. (1967). Polyglycerol esters. Food Engineering, 5, 79-82.

Riisom, T., Krog, N. and Eriksen, J. (1984). Amylose complexing capacities of cis- and trans-unsaturated monoglycerides in relation to their functionality in bread. Journal of Cereal Science, 2, 105-118.

Razavi-Rohani, S.M. and Griffiths, M.W. (1994). The effect of mono and polyglycerol laurate on spoilage and pathogenic bacteria associated with foods. Journal of Food Safety, 14, 131-151. 